\title{
CHST15 Gene
}

National Cancer Institute

\section{Source}

National Cancer Institute. CHST15 Gene. NCI Thesaurus. Code C118522.

This gene is involved in chondroitin sulfate metabolism. 